\title{
Expectations of Competency: The Mismatch between Employers' and Graduates' Views of End-User Computing Skills Requirements in the Workplace
}

\author{
Shirley Gibbs and Gary Steel \\ Lincoln University \\ Christchurch, New Zealand
}

shirley.gibbs@lincoln.ac.nz; gary.steel@lincoln.ac.nz

\author{
Alison Kuiper \\ The University of Sydney \\ Sydney, Australia
}

alison.kuiper@sydney.edu.au

\section{Executive Summary}

The use of computers has become part of everyday life. The high prevalence of computer use appears to lead employers to assume that university graduates will have the good computing skills necessary in many graduate level jobs. This study investigates how well the expectations of employers match the perceptions of near-graduate students about the computing skills necessary for the workplace.

Four graduate-level positions were identified from advertisements placed in order to recruit graduates. The employers who placed these advertisements were interviewed, as were 21 students about to graduate from a university commerce programme. It was determined that the wording of the advertisements did not satisfactorily portray the requirements and intentions of the employers. Employers, unsure in many cases of how to request the skills they needed, assumed that graduates' end-user computing skill would be at a level suitable for entry into the workplace. Students close to graduating, while accepting that computers would be a part of their daily work life, had no idea of the type of computing skills employers would expect.

This study highlights implications for three groups: employers, graduates, and educators. With the implications in mind the following recommendations are made:

Employers are encouraged to:

- Modify their assumptions about graduate's computer literacy

- Communicate their needs clearly to new graduates

- Communicate with tertiary education providers about their workplace requirements

Material published as part of this publication, either on-line or in print, is copyrighted by the Informing Science Institute. Permission to make digital or paper copy of part or all of these works for personal or classroom use is granted without fee provided that the copies are not made or distributed for profit or commercial advantage AND that copies 1) bear this notice in full and 2) give the full citation on the first page. It is permissible to abstract these works so long as credit is given. To copy in all other cases or to republish or to post on a server or to redistribute to lists requires specific permission and payment of a fee. Contact Publisher@InformingScience.org to request redistribution permission.
Graduates are encouraged to:

- Make themselves aware of the types of computing that workplaces require

- Be more circumspect when it comes to evaluating their own end-user computing skills 
Educators are encouraged to:

- Modify student profiles to match those of graduating students

- Communicate with employers regarding the domain and non-domain skill set required by graduates

- Not be surprised if new students arrive to study without the level of end-user computing required to complete a degree

This study highlights the difficulties employers have trying to express their end-user computing requirements in job advertisements and the different interpretations that graduates make when reading the advertisements. Employers assumed that all graduates would have good computing skills, and students had high levels of confidence in their computing ability but little understanding of workplace computing requirements. The results of this study indicate that this is an issue that requires consideration by both sides of the employment process.

Keywords: Computer literacy, workplace computing, computer self-efficacy, end-user computing, graduate's computing skills.

\section{Introduction}

Computers are found everywhere in day-to-day life. Home ownership of computers is not considered unusual; neither is the presence of a computer in classrooms at all levels of education. The prevalence of this technology has contributed to the expectation that new business graduates will have workplace ready computing skills. However, the way the required computing skills can be described is often confusing. Just glancing through the employment section of any newspaper or positions advertised on employment web sites is enough to reveal that there are many different ways of expressing the computing requirement. Advertisements for what appear to be similar roles may use completely different terminology to describe the end-user computing skills required. Most use broad terms and statements such as "Must be computer literate"; "Expert in Word and Excel" and "Strong MS Office skills".

Coupled with the use of these generic terms are the equally generic meanings that employers place on these and the understanding, and misunderstanding, that graduates derive from reading them (Holtzman \& Kraft, 2010; Kavanagh \& Drennan, 2008).

There is literature available regarding the skills necessary to succeed in the Information Technology (IT) field once a person graduates but not a great deal regarding the end-user IT skills needed to succeed in a general business area (Chau, Huang \& Chen, 2003; Fink \& Neumann, 2007; McMurtrey, Downey, Zeltmann \& Friedman ,2008). However, Kim, Hsu and Stern (2006) in their study of end-users who had been trained in the IT area, concluded that there is a real need for people with genuine end-user computing skills in all business positions. Kim et al. (2006) contend that, in order to reduce any gap in skills, universities should be encouraged to put more focus on the type of end-user computing at university as well as on the more traditional academic computing skills.

A 2001 study undertaken by Rainsbury, Hodges, Busrchell, and Lay asked students and graduates from the business studies department of a tertiary institution to rank the skills for entering the workforce in order of importance. Participants ranked computer literacy, customer service orientation, teamwork and co-operation, self-confidence, and willingness to learn most highly. Rainsbury et al. (2001) found the graduates already in the workforce were more likely to rank "hard" or more technical skills as more important than "soft" or non-technical skills. This differed from the opinions of those who were current students. These participants considered interpersonal skills more important. Rainsbury et al.'s survey ranked computer literacy as being the highest ranked overall (hard and soft) skill necessary to enter the workforce. 
Similarly, an analysis of 100 job advertisements by R. Bennett (2002) considered a range of transferable skills that employers expect university graduates to have when entering the workforce. Transferable skills were defined by Bennett as those skills required in any job which allow workers to be flexible and adaptable between workforces. These skills included communication, literacy, team work, problem-solving, and IT skills. The employers placed a great deal of importance on graduates having transferable skills. It was expected, by these employers, that the university system would, by default, provide graduates with a comprehensive set of transferable skills. However, Bennett noted that few employers were willing to produce definitive descriptions of these transferable skills. Instead, they used broad and somewhat vague terms to describe them.

Although indicators such as job advertisements ostensibly provide an objective measure of employers' demands, they do not usually describe the level of competence required in each skill area. If there is no shared understanding of the precise skill attributes and level sought by a firm, candidates will not know exactly what they are being asked to demonstrate, and universities cannot know what they need to teach (R. Bennett, 2002). Venables and Tan (2009) say that it is the responsibility of educational institutions to better prepare their graduates for entry into the workplace. They say that better preparation is possible if educators create workplace experiences for their students, thereby also encouraging stronger links between the business world and education and lessening any gaps which may exist when a graduate enters the workforce. On the other hand, Tomlinson (2007) believes that graduates are now aware that the transition from study to work is less easy than it may once have been. Tomlinson asserts that these graduates also realise that the first job they get will be a pathway to other positions, rather than a 'job-for-life', as once it may have been, and therefore they will need to continue to increase their skills on the job.

In a seventeen-year content analysis of employment advertisements requesting IT skills, Gallivan, Truene, and Kvasny (2004) noted that people entering the workforce in the 21 st century are expected to have a higher level of IT skills than would have been expected previously. While their study predominately focused on IT roles, they contend that one of the main areas which was lacking was that of end-user support. This suggests both that support is required now more than ever, due to the increase in the number of end-users in the general workforce, and that not all end-users are equipped to handle all the problems they may encounter.

Murray, Sherburn, and Perez (2007) surveyed employers from ten US manufacturing companies. All employers reported that MS Office skills were required by employees at "all levels". The study concluded that employers have higher expectations of university graduates' knowledge and use of IT than they do of non-graduates. Graduates were expected to arrive in the workplace with a higher base set of IT skills. They noted that despite having such expectations, employers had trouble in articulating the actual competencies sought. The authors concluded that computer literacy was a moving target and urged both employers and educators to continue to give credence to its importance in the workplace. Murray et al. (2007) noted that computer literacy was likely to become the most important form of literacy as businesses became more reliant on technology.

It is evident from the literature on workplace skills that employers have the expectation that graduates would have 'good' computing skills. The younger generation has attracted a great deal of attention concerning their learning styles and technology usage. This attention has left them with several 'nicknames'; for example, net-generation or digital natives (Prensky, 2001a, 2001b). Prensky and others suggest that this generation has an advanced knowledge and appreciation of technology because they have grown up surrounded by technology. Although this view might apply to some, it is certainly not a 'one size fits all' scenario and it is important to remember that the exposure may amount to little more than playing games or interacting with peers on social networking sites. There are many members of this 'net-generation' who struggle with new technology (Kennedy, Krause, Judd, Churchward, \& Gray, 2008). While there is general agreement that access to technology has increased significantly over the last two decades, there is not indis- 
putable evidence that the current generation have better skills than members of other generations (S. Bennett, Maton, \& Kervin, 2008; Childers, 2003; Hoffman \& Blake, 2003 Hoffman \& Vance, 2005; Kennedy et al, 2006; Werner, 2005). What can be problematic is not only accurately transferring employer expectations into descriptions of job requirements, but creating accurate expectations on the part of both the employers and the new graduates regarding the graduates' skill levels.

When a person is applying for a job in a specific IT area they are likely to be faced with some kind of test, such as debugging code or explaining an application they have developed. Likewise, when a person applies for an office-based job at secretarial or administrative level they might need to demonstrate their computing ability. However, frequently where a business is looking to employ recent graduates for entry-level positions in the business area no computer skill testing is involved The businesses concerned are understandably interested in an applicant's knowledge in the key domain (marketing, finance, etc.), and often assume that the appropriate level of computing skill has been acquired during the course of the applicant's education. There might, therefore, be no mention of computing at the interview or the applicant's own self-assessment might be relied on.

People's perception of their ability is reflected in their perceived self-efficacy with respect to a particular task. Self-Efficacy Theory (Bandura, 1977) is based on social cognitive theory. Selfefficacy, itself, is defined as a person's belief in their ability in specific situations. Computer selfefficacy (CSE) is derived from Bandura's theory. CSE refers to a person's perception of their computing ability (Compeau and Higgins, 1995). This theory suggests that people's perception of their ability in certain tasks can very much depend on the referent individual or group to whom they are comparing themselves, and on the past experiences they have had with computer tasks (Karsten \& Schmidt, 2008; Wood, 1989). The original Self-efficacy Theory postulated three evaluative dimensions: strength, magnitude and generalizability. These dimensions were defined for CSE by Compeau and Higgins (p. 192, 1995) in the following manner:

- Strength: This dimension of CSE refers to the confidence an individual has concerning his or her ability to execute various computing tasks.

- Magnitude: Individuals with high CSE magnitude might be expected to perceive themselves as able to accomplish more difficult computing tasks.

- Generalizability: CSE generalizability reflects the scale to which judgment is limited to a particular domain of activity. An individual might have high CSE using the Internet but low CSE when asked to design a database.

Self-efficacy is seen by some as being a better predictor of performance than actual capability because a person's judgments, based on prior experience, often determine how a person would use the skills and knowledge they have in specific domains (Smith, 2001).

\section{Purpose of the Study}

After reviewing the literature above, the question arose as to whether employers' descriptions of advertised job vacancies were clear enough to convey to the graduates the level of computing skill required for graduate level employment. A second, and very much related, question had to do with graduates' interpretations of such advertisements: How closely do these interpretations match the employers' actual requirements? Last, how well did the graduates believe they were able to undertake the perceived requirements, and why? 


\section{Method}

Four job advertisements, considered to be representative of positions for which business graduates would apply (see Table 1), were selected from a widely circulated newspaper published in the city in which the students' university was located and from an online employment website that listed a variety of jobs both nationally and internationally. Each of the positions specifically requested a particular business degree as a requirement and included a brief description of computing requirements in the advertisement. The four employers who submitted these advertisements agreed to take part in the study. For the purpose of the study, the people interviewed were those who had some responsibility for the preparation of the job advertisements. These participants were interviewed about their expectations regarding the level and breadth of computing skill they expected of applicants.

Table 1 - Summary of Job Advertisements

\begin{tabular}{|c|l|l|l|l|}
\hline Case 1 & $\begin{array}{l}\text { Position } \\
\text { Title }\end{array}$ & $\begin{array}{l}\text { Degree Type } \\
\text { Sought } \\
\text { Assistant }\end{array}$ & $\begin{array}{l}\text { Type of Or- } \\
\text { ganisation }\end{array}$ & $\begin{array}{l}\text { Key Phrase Used to } \\
\text { Describe Computing Skill }\end{array}$ \\
\hline Case 2 & $\begin{array}{l}\text { Customer } \\
\text { Service }\end{array}$ & Any & $\begin{array}{l}\text { Online Market- } \\
\text { ing }\end{array}$ & $\begin{array}{l}\text { Can handle most Office com- } \\
\text { puter programs }\end{array}$ \\
\hline Case 3 & $\begin{array}{l}\text { Graduate Ac- } \\
\text { countant }\end{array}$ & Accounting & Accountancy & $\begin{array}{l}{[\text { Computing not specified in }} \\
\text { advertisement }]\end{array}$ \\
\hline Case 4 & $\begin{array}{l}\text { Assistant Ac- } \\
\text { countant }\end{array}$ & $\begin{array}{l}\text { Accounting } \\
\text { or Finance }\end{array}$ & Government & $\begin{array}{l}\text { Good on computers - espe- } \\
\text { cially spreadsheet and data- } \\
\text { bases. }\end{array}$ \\
\hline
\end{tabular}

Twenty-one business degree students (mean age of 20 years) were interviewed. These were all final-year, business degree students studying various majors of a Bachelor of Commerce Degree. These majors included accountancy, marketing, management, and finance. Initial recruiting of these participants took place in one of their final year classes. A brief presentation about the study was made by the first author and volunteer participants were solicited. Several students from each of these classes indicated a desire to take part in the study. There were more potential participants than time or resources allowed, so a random selection was made from those who indicated an interest. These students were approached for participation. Of the twenty-one students taking part, eleven were female and ten were male.

Qualitative data was collected using semi-structured interviews. After being shown the four job advertisements, the student was asked to give his or her interpretation of the computing expectation for each position. Because the use of open-ended questions allows for the identification of patterns, trends and themes (Babbie, 2007, pp 246), the main portion of the interviews were based on two such questions:

1. After reading the advertisement what is your interpretation of the computing skills required?

2. How well do you think your current computing skills would match with your perception of what is required?

Other questions asked for various demographic data (age, sex), as well as, in the case of the students, their educational background in computing. 
The data analysis involved transcribing all interviews in full and reading through the transcriptions to create response categories. All interview transcriptions were then re-coded for the presence of these categories and, during this process, common themes with regard to the participants' answers were identified.

\section{Results and Discussion}

The interviews with students and employers produced some interesting, but not completely unexpected, results. The data has showed that several, very different interpretations can be derived from one advertisement. In all of the cases there was a range of understanding of the computing terms used to describe the computing requirements for the role.

For the Marketing Assistant position (Case 1), students believed they knew what would be required of them in this role. Typical responses included such remarks as:

\section{MSOffice or something like that. Word or Excel and as a Marketing As- sistant you would need Power Point because Marketers do lots of pres- entations. (Student 10)}

Need to be able to use Office. That shouldn't be an issue because anyone who can use a computer can use Office. (Student 19)

When asked to define what he actually meant by the use of the phrase "Can handle most Office computer programs", Employer 1 said:
In this position we wanted a bit more with Photoshop work and we have an internal system which is an accounting system which we would ex- pect the assistant to be able to manipulate to get data and forms into Excel worksheets from information they can get out of that into the sys- tem...so that is pretty much the requirements we were looking at for this position.

Here we see a clear difference between the students' interpretation of the requirements and those that were in Employer 1's mind. In addition, whereas the phrase the employer used in the advertisement could be described as ambiguous, in person he provided a detailed explanation of the skill set required. These results indicate that those writing the advertisements may, at times, be too economical in describing the computing needs of a role. This economy may arise because employers have certain expectations of a graduate's abilities operating a computer and believed those abilities to be implicitly covered in the advertisement, or because the employers have little experience in writing advertisements that include computer skill requirements.

A similar pattern of differences in expectations and interpretations was found in Case 2 (the Customer Services role). As before, the students appeared confident they knew from the advertisement, what the computing tasks and skill level would be in the job. Common types of responses included:

Good keyboard skills mean quite fast typing. Strong computing would mean knowing how to turn a computer on and off and knowing how to fix it if there was a problem. (Student 2)

Sounds like general Word processing. They probably want high words per minute rate. (Student 4 )

In contrast, Employer 2 defined the company's computing requirement by saying:

We are looking for someone who can do everything [computer-wise] in the office: email, data entry-usually into a database also there is a 
trouble shooting aspect -we are always looking for process improvement. We expect that the person will be competent using a mousethinking before you enter information and will have a sense of where they are in terms of making errors.

The variability of the interpretations of the advertisements by the students occurred for each of the positions. This often appeared to be due to selective attention towards specific words or phrases in the copy. Some of the students read the whole advertisement and used all the information given when making their interpretations. Others appeared to emphasise only the terms used to describe the computing required or ignored some of the words in the descriptive phrases. By limiting their focus when reading the advertisements, the students were, possibly, seeking out a skill or task with which they felt comfortable; perhaps an area of self-efficacy. One example of this limited attention occurred in Case Two. Here, some participants focussed on the words Strong and Keyboard (from the phrase 'Strong computing and keyboarding'), combined these words, and then went on to interpret this as meaning "being able to touch-type."

Employers in the current study generally expressed the opinion that any graduate would have the necessary computing skills once they had completed a degree. In fact, there was a widespread, if somewhat vague, opinion amongst both groups that anyone, but especially the younger generation, can simply "use computers". Employer 3, for example, stated that he believed that someone who had completed a university degree must be able to use Word and Excel to a reasonable level, and Employer 4 said that he thought anyone who was 25 or younger "knew computers inside out". However, Wallace and Clariana (2005) have noted that, while it is often assumed that incoming business students would have the necessary computing skills to get them through their degrees and out in to the business world, this is often not the case. This assumption is not only commonly made about those graduating from university but is also applied to younger people in general. This is partly because of the availability of computing technology and young people's use of it. This difference between the employers' assumptions and students' interpretations of the advertisements revealed a worrying gap. Students quite clearly did not have an accurate perception of the skills they would be expected to have when entering the workplace. Even when students felt they knew which skills the employer was requesting, they were not always sure how or why these skills would be used. This did not daunt their self-confidence, however. While it is apparent from the results that the students had different understandings of the computing skills required in the workplace, there was generally little evidence of concern that they might lack the necessary computing skills. The results revealed the students' belief that any deficiencies in their knowledge would be covered by training the employers would offer. One of the students, an accounting student, thought that most accounting companies would offer training for dedicated accounting software. Another student looking for a business or marketing role volunteered that, while she thought that she probably had enough skill, she would not be afraid, even at the interview stage, to ask for training. A third participant (Student 9) stated, "No I don't expect that they will already think I can use this type of software - there will be some training involved."

The students' belief that they would not be expected to have specific skills echoes the results of Hoffman and Vance's (2008) study of students in a computing class. Their participants, like the participants in the current study, were surprised that employers might expect them to have specific IT skills when they begin employment.

Our students were concerned to know future employers' expectations for technology knowledge and use, though they assumed that employers are willing to train employees on career-specific technology and applications (Hoffman and Vance, 2008, p. 95).

Perhaps, given their general lack of workplace experience, it is not surprising that the students' perceptions were varied and confident. As Caputo and Dunning (2005) have pointed out, when a 
person is unsure about something they are more likely to make unsuccessful interpretations as to their skill in that area. People who have successfully gained employment might be more skilled at interpreting the requirements of a job than those with no experience (Leung, 2007, Venables \& Tan, 2009).

Employers in the current study were looking for a range of supporting skills, including computing and communication, as well as particular domain knowledge. They assumed these skills would be acquired at university and that it would not be the role of the employer to provide them. This assumption supports the findings of both Crebert, Bates, Bell, Patrick, \& Cragnolini (2009) and Murray et al. (2007). Employers in the current study said that they assumed that graduates would, after having completed a degree, have all the necessary computing skills. Employer 4 was the sole employer who mentioned training sessions, saying that he often set up staff training - not necessarily focused on computing - when a gap was observed. This expectation by the students that training would be available might not be welcomed by many employers, especially those running smaller companies. As Skok and Bian (2007, p.9) state, "Because small practices work within tight budget constraints, they will always seriously consider...[the] cost of training; loss of fee generation income ...; [and] cover for client work when a staff member is away for training as well as staff movement". It is likely that the most positive interpretation of students' expectations about training is that, as Tomlinson (2007) has reported, current students are aware that they will need to continue to learning in the workplace to further their careers.

\section{Limitations and Future Research}

This study was primarily interested in the how employers expressed the end-user computing requirement in non-computing roles, and what expectations near graduates had of computing skills for the workplace. While the numbers for both groups of participants were small, the results certainly suggest that there is a mismatch between employers' computing skills expectations and the students' interpretations of those expectations. A second limitation to this study was that only a perception of ability was sought from the student participants. It is difficult to know if they, as a group, actually have the workplace-ready computing skills they say they do. Future work will endeavour to gain evidence of actual computing skills business graduates have to match these with the requirements of those who will employ them.

\section{Conclusions and Recommendations}

The primary conclusion to be drawn from our study is that there was a serious mismatch between employers' and students' expectations about the type and level of computing skills required for employment. There were several reasons identified for this, but it was clear that employers found it difficult to express what it was that they actually required in the way of computing skills, and students interpreted these rather ambiguous descriptions at the lowest possible level. Employers assumed that because a graduate had been to university and was young, that he or she would be able to use computers proficiently in a business situation. The students, for their part, were confident in their ability, but most were not aware of the skills that would be required in the business world.

One major implication of this study is that if the lack of communication between employers and prospective employees continues, employers may not be able to find graduates with the level of computing skill they are seeking. If students feel that it is unnecessary to attain high levels of computer skills, possibly because of the expectation of on-the-job training, then there is little post-university incentive for them to acquire the desired skills. This implication highlights the need to make recommendations to employers, students about to graduate, and those responsible for educating those students. 


\section{Recommendations for Employers}

The principal issue that should concern employers is the lack of clear communication in conveying job requirements to new graduates. This study has shown that students have been unable to correctly determine the requirements of a job from reading the descriptions provided in job advertisements. Employers are encouraged to modify their assumptions about the computing abilities of graduates and to provide detailed information about the computing skills required for a position. Employers are also encouraged to communicate with educators about the nature of the skills that graduates are expected to have when beginning work in order to reduce the gap between skills and expectations.

\section{Recommendations for Graduates}

One of the main outcomes of this study was a revelation about the misperceptions held by student participants regarding the computing skills required for the workplaces they are likely to enter. These misperceptions appeared to be based on the level of computing skill they would possess when graduating. Often, these requirement perceptions were at a much lower level than the employers had of the computing skill level graduates would possess on entering employment. Graduates are encouraged to seek advice directly from employers regarding the skills they are likely to need in the workplace. We also advise them to enter into a dialogue with those educating them, to insure that those skills will be taught.

\section{Recommendations for Educators}

Recommendations in this section are intended for those designing the programmes rather than those individuals teaching into a programme.

Educators are cautioned not to expect that all those arriving at university will have, by virtue of their belonging to a particular generation, the necessary computing skill set to be ready for the workplace without any formal computing tuition. While young people do use computers and associated technology regularly, this use is more likely to be for social rather than professional needs. Although computer use and available software have advanced, it may still be necessary for graduates to receive formal tuition in the skills that will be required to prosper in the workplace. Those designing programmes of study are urged to talk to employers regarding both the domain and non-domain skill set required of graduates so these skills can be accommodated within programmes of study and reflected in graduate profiles.

\section{Summary}

In summary, this study has highlighted the differences between the requirements that employers are trying to express when placing job advertisements and the interpretations that graduates make when reading job advertisements. Employers made the assumption that all graduates would have good computing skills, and the students, after little formal training, had high levels of confidence in their computing ability but little understanding of workplace computing requirements. This study has demonstrated that this is an issue that requires consideration by all those involved all sides of the employment process. 


\section{References}

Babbie, E. (2007). The practice of social research (11th ed.). Belmont, CA, USA: Thomson-Wadsworth, Thomson Higher Education. ISBN: 0-495-09325-4.

Bandura, A. (1977). Social learning theory. Alexandria, VA: Prentice Hall. ISBN 0138167443.

Bennett, R. (2002). Employers' demands for personal transferable skills in graduates: A content analysis of 1000 job advertisements and an associated empirical study. Journal of Vocational Education and Training, 54(4), 457 - 476.

Bennett, S., Maton, K., \& Kervin, L. (2008). The 'digital natives' debate: A critical review of the evidence. British Journal of Educational Technology, 39(5), 775 - 786.

Caputo, D., \& Dunning, D. (2005). What you don't know: The role played by errors of omission in imperfect self assessments. Journal of Experimental Social Psychology, 4, 488 - 505.

Chau, M, Huang, Z., \& Chen, H. (2003). Teaching key topics in computer science and information systems through a web search engine project. ACM Journal of Educational Resources in Computing, 3(3), September 2003, Article 2.

Childers, S. (2003). Computer literacy: Necessity or buzzword? Information Technology and Libraries, 22(3), 99 - 104. Retrieved from http://digitalcommons.unl.edu/libraryscience/90

Compeau, D. R., \& Higgins, C. A. (1995). Computer self-efficacy: Development of a measure and initial test. MIS Quarterly, 19(2), $189-211$.

Crebert, G., Bates, M., Bell, B., Patrick, C., \& Cragnolini, V. (2009). Ivory tower to concrete jungle revisited. Retrieved on 02/05/2009 from: http://www.gu.edu.au/centre/gihe/griffith_graduate/GG4report.pdf

Fink, L., \& Neumann, S. (2007) Gaining agility through IT personnel capabilities: The mediating role of IT infrastructure capabilities. Journal of the Association for Information Systems, 8(2), 440-462.

Gallivan, M. J., Truene, D.P., II, \& Kvasny, L. (2004). Changing patterns in IT skill sets 1988-2003: A content analysis of classified advertising. The Data base for Advances in Information Systems, 35(3), $64-87$.

Hoffman, M., \& Blake, J. (2003). Computer literacy: Today and tomorrow. Journal of Circuits, Systems, and Computers (JCSC), 18(5), 221 - 233.

Hoffman, M. \& Vance, D, (2005). Computer literacy: What students know and from whom they learned it. SIGCE'05, Feb 2005, St Louis Missouri, USA, 356 - 360.

Hoffman, M. \& Vance, D, (2008). Computer literacy: A student-oriented perspective. Consortium for Computing Sciences in Colleges. CCSC: North-eastern Conference, 90 - 96.

Holtzman, D. M., \& Kraft, E. M. (2010). Skills required of business graduates: Evidence from undergraduate alumni and employers. Business Education \& Administration, 2(1), 49-59.

Karsten, R., \& Schmidt, D. (2008). Business student computer self-efficacy: Ten years later. Journal of Information Systems Education, 19(4), 445 - 455.

Kavanagh, M. H., \& Drennan, L. (2008). What skills and attributes does an accounting graduate need? Evidence from student perceptions and employer expectations. Accounting \& Finance, 48(2), 279-300. doi:10.1111/j.1467-629X.2007.00245.x.

Kennedy, G., Krause K., Judd, T., Churchward, A., \& Gray, K. (2008). First year students' experience with technology: Are they really digital natives? Australasian Journal of Educational Technology, 24(1), $108-122$

Kim; Y., Hsu; J, \& Stern, M. (2006). An update on the IS/IT skills gap. Journal of Information Systems Education; 17(4), 395 - 403. 
Leung, H. (2007).The impact of information quality of job descriptions on an applicant's decision to pursue a job. Retrieved on 29/03/2009 from: http://uwspace.uwaterloo.ca/bitstream/10012/3310/1/Harry\%20Leung\%20MASc\%20Thesis.pdf

McMurtrey, M. E., Downey, J. P., Zeltmann, S. M., \& Friedman, W. H. (2008). Critical skill sets of entrylevel IT professionals: An empirical examination of perceptions from field personnel, Journal of Information Technology Education, 7, 101-120. Retrieved from http://www.jite.org/documents/Vol7/JITEv7p101-120McMurtrey312.pdf

Murray, M., Sherburn, R., \& Perez, J. (2007). Information technology literacy in the workplace: A preliminary investigation. Proceedings of the 2007 Southern Association for Information Systems Conference, $132-136$.

Prensky, M. (2001a, September/October). Digital natives, digital immigrants. On the Horizon, 9(5), 1 - 6.

Prensky, M. (2001b, November/December). Digital natives, digital immigrants: Part 2: Do they really think differently? On the Horizon, 9(6), 1 - 6.

Rainsbury, E., Hodges, D., Burchell, N., \& Lay, M. (2001). Ranking workplace competencies: Student and graduate perceptions. Asia-Pacific Journal of Co-operative Education, 3(2), 8 - 18.

Skok, W., \& Bian, T. (2007). What business people need to know about IT: An accounting perspective. Strategic Change, 16, 57 - 68. Published online in Wiley Inter Science (www.interscience.wiley.com) DOI: $10.1002 / j s c .780$.

Smith, S. (2001). An examination of the computer self-efficacy and computer-related task performance relationship. Retrieved on 13/03/2009 from http://www.osra.org/2001/smith.pdf

Tomlinson, M. (2007). Graduate employability and student attitudes and orientations to the labour market. Journal of Education and Work, 20(4), 285 - 304.

Venables, A., \& Tan, G. (2009). Realizing learning in the workplace in an undergraduate IT program. Journal of Information Technology Education, 8, IIP17 - 26. Retrieved from http://www.jite.org/documents/Vol8/JITEV8IIP017-026Venables706.pdf

Wallace, T, \& Clariana, R.B. (2005). Perception versus reality - Determining business students' computer literacy skills and need for instruction in information concepts and technology. Journal of Information Technology Education, 4, 141 - 151. Retrieved from http://www.jite.org/documents/Vol4/v4p141151Wallace59.pdf

Werner, L. (2005). Redefining computer literacy in the age of ubiquitous computing. SIGITE 05, 95 - 99.

Wood, J.V (1989). Theory and research concerning social comparisons of personal attributes. Psychological Bulletin 1989, 106(2), 231 - 248.

\section{Biographies}

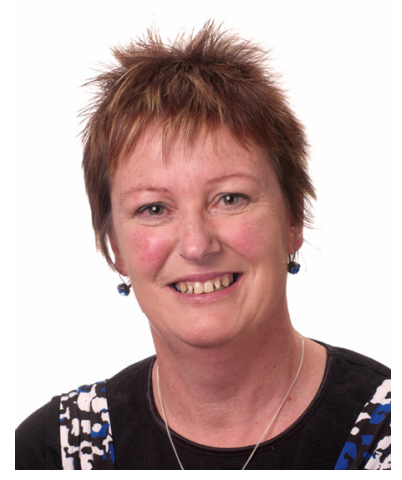

Shirley Gibbs is a Lecturer in the Department of Applied Computing at Lincoln University, Christchurch, New Zealand. Her research interests include end-user computing, assessment of end-user computing skills, the relationship between computer skill self-assessment and personality, computer literacy and computing education. 


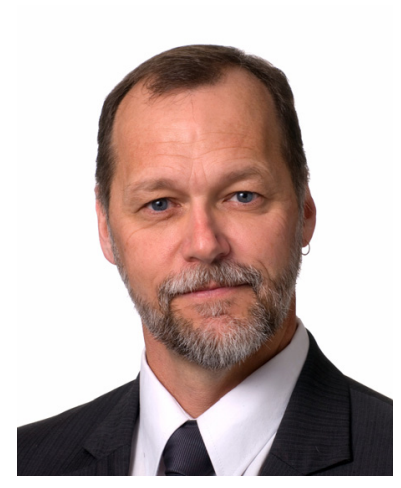

Gary Steel is a Senior Lecturer in Social Psychology in the Department of Social Science, Parks, Recreation, Tourism \& Sport at Lincoln University, Christchurch, New Zealand. His research interests include psychological adaptation and adjustment to extreme and unusual, place attachment, social networks, and the relationships between innovation, technology use, and personality.

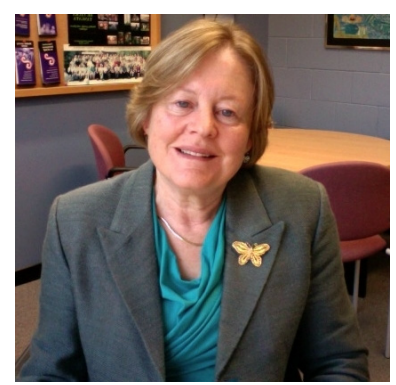

Alison Kuiper is a Senior Lecturer in the Institute for Teaching and Learning at the University of Sydney, Sydney, Australia. Her research interests include tertiary education policy and practice, education and employment, teaching and learning strategic development and intercultural and cross-cultural communication. Prior to joining the Institute for Teaching and Learning Alison was the Manager of Teaching and Learning Services at Lincoln University, Christchurch, New Zealand. 